Irena Prosenc Šegula

\title{
»Zgodovina ne teče naravnost, cikcakasto gre«: percepcija časa $v$ Magrisovem romanu Na slepo
}

Ključne besede: sodobna italijanska književnost, Claudio Magris, čas, zgodovina, identiteta, mit, Argonavti

\section{Uvod}

Prvoosebni pripovedovalec v Magrisovem romanu Na slepo (Alla cieca, 2005) slikovito pove, da "zgodovina ne teče naravnost, cikcakasto gre, že od nekdaj; razburja se, vendar miruje, kot gneča, ki se na rock koncertu preriva, suva, dreza « (Magris, 2009, 60). ${ }^{1} \mathrm{~V}$ delu, ki ga D. Jančar v spremni besedi k slovenskemu prevodu označi kot »roman o halucinacijah, deliriju in shizofreniji zgodovine« (Jančar, 2009, 310), se percepcija časa izraža predvsem skozi razmišljanje o zgodovini, o njenem nenehnem ponavljanju in neopredeljivosti njenih časovnih razsežnosti. Tako koncept časa kot sam avtodiegetični pripovedovalec pa sta $\mathrm{v}$ besedilu problematizirana, saj pripovedni glas privzema različne identitete, povezane z zgodovinskimi obdobji, ki segajo vse od konca 18. stoletja do devetdesetih let 20. stoletja.

\section{Razmišljanje o zgodovini}

Zgodovina je ena osrednjih tematik romana tržaškega književnika, ki mu A. Ciccarelli utemeljeno pripisuje "potrebo, da raziskuje preteklost, a ne zato, da bi se sedanjosti izognil, temveč da bi jo odkril in bolje spoznal «(Ciccarelli, 2004, 411). ${ }^{2}$ Protagonistova identiteta ali, bolje, identitete se izoblikujejo predvsem pod vplivom zgodovinskih dogodkov. Pripovedovalec, ki se oglaša z nedoločenega kraja (sam je prepričan, da je na Tasmaniji, medtem ko njegov zdravnik meni, da se zdravi v psihiatrični bolnišnici v Barkovljah pri Trstu), privzame različne identitete, ki so vse po vrsti povezane z zgodovino. Med njimi sta poglavitna Danec Jorgen Jorgensen in Tržačan Salvatore Cippico. Prvi je resnično obstajal, drugi je fiktiven, oba pa sodita med like, katerih življenja so zgodovinsko nepomembna in ki predstavljajo, z Magrisovimi

1 Od tu naprej bodo navedki iz tega romana označeni samo s številko strani.

2 Vsi prevodi iz tujejezičnih besedil, ki doslej še niso prevedena v slovenščino, so delo I. Prosenc Šegula. 
besedami, „v knjigi zgodovine zgolj kratke opombe pod črto« (Ciccarelli, 2004, 410). A prav takšni liki so Magrisu posebej ljubi, saj vidi smisel literature tudi v tem, da ohranja spomin na te drobne usode, jim z literarnimi besedili gradi »krhko Noetovo barko iz papirja « in jih tako poskuša »rešiti pred reko časa, da jih ne izbriše val pozabe« (Magris, L'infinito, 2005, XVII).

Jorgen Jorgensen (1780-1841) je pustolovec in pomorščak. Udeleži se odprave, ki leta 1803 na Van Diemenovi zemlji, današnji Tasmaniji, v izlivu reke Derwent ustanovi prvo kazensko kolonijo, ta pa se pozneje razvije v tasmansko glavno mesto Hobart. V ozadju zgodovinskih dogodkov prve polovice 19. stoletja Jorgensen živi na moč razburkano življenje. Leta 1809 na Islandiji sproži kratko, komaj nekajtedensko revolucijo, razglasi neodvisnost otoka od Danske in se proglasi za njegovega "protektorja«. V naslednjih letih v Londonu zaradi pretiranega popivanja in igranja na srečo zabrede v visoke dolgove, ki ga večkrat privedejo v zapor. Zaradi njih je celo obsojen na smrt, pozneje pa mu kazen omilijo in ga leta 1826 deportirajo v kazensko kolonijo na Van Diemenovi zemlji, ki jo je dobrih dvajset let poprej sam pomagal ustanoviti. Čez nekaj let je sicer deležen delne svobode, vendar pa na otoku ostane vse do svoje smrti leta 1841 .

Drugi lik, Salvatore Cippico, je udeležen v zgodovinskih dogodkih 20. stoletja. Rodi se italijanskemu izseljencu na Tasmaniji leta 1910, vendar ga kot komunista iz Avstralije izženejo v Italijo. V španski državljanski vojni se bori na strani mednarodnih brigad, med drugo svetovno vojno pa se kot italijanski vojak znajde v Dalmaciji. Po italijanski kapitulaciji se pridruži jugoslovanskim partizanom, vendar ga zajamejo Nemci, ki ga deportirajo v Dachau. Po vojni leta 1947 emigrira v Jugoslavijo skupaj $\mathrm{z}$ dva tisoč delavci iz tržiških ladjedelnic, ki želijo prispevati k izgradnji socializma $\mathrm{v}$ novi Titovi državi. A po Titovem sporu s Stalinom ga jugoslovanske oblasti leta 1949 obtožijo informbirojevstva in ga, tako kot številne druge italijanske komuniste, zaprejo na Goli otok. Od tam mu uspe prebegniti v Italijo, kjer pa ne najde več prostora pod soncem. Italijanska družba namreč postrani gleda komuniste, ki so prostovoljno odšli v Jugoslavijo, medtem ko se je moralo 300.000 Italijanov izseliti iz Istre in z Reke. Še huje ga prizadene, ko mu obrne hrbet tudi italijanska komunistična partija, ki se je, medtem ko so bili tržiški delavci v jugoslovanskih zaporih, odrekla svoji stalinistični usmeritvi, tako da so ti postali neprijetne priče njene preteklosti. Cippico spričo vsega tega leta 1951 emigrira v Avstralijo.

Protagonist, po lastnih besedah »agent svetovne zgodovine« (168), se zaveda svoje močne identifikacije $\mathrm{z}$ zgodovino:

V zgodovini se dobro znajdem. Ob zgodovinskih dnevih moraš biti prisoten, čeprav jih je vedno več. Kaj pa je človek, sam s svojim življenjem, brez 
znamenitih novic, ki ga osvetljujejo, kot ožarjajo ognjemeti zbrano množico v temi? Senca je, mrakoba. Moraš biti tam, kjer je usoda, stopati za njo kot njena častna straža in korakati pod njenimi slavoloki, medtem ko se iz teme, ki se širi z obeh strani, dviga ploskanje - ali pa zmerjanje, saj ni pomembno (182).

Pripovedovalčevi eksplicitni komentarji nakazujejo tudi na to, da posamezne identitete izgubljajo svojo samostojnost in se zlivajo v kolektivno, "zgodovinsko« identiteto številnih jazov, ki trpijo v sistemu ponavljajočih se represivnih zgodovinskih vzorcev. Tako se pripovedovalec predstavi kratko malo kot: »jaz; moje ime je tu in me ne briga, če se tudi mnogo drugih tako piše« (183). O svoji identiteti razmišlja v množini: »kdo sem, kdo smo« (39), »ti, ki si mnogi« (166). Svoje življenje primerja z življenji številnih drugih, meje med njimi pa so zabrisane: »svojega življenja, no, mojega, njegovega, kdo ve, čigavega« (7), saj jih ponazarjajo "ploščice mojega spomina, spomina drugih, spomina vseh«(307). Vse številne identitete druži njihova tesna navezanost na zgodovino, ki pa nanje vpliva predvsem negativno in nasilno:

Kaj pa morem, v vsej tej zmešnjavi, z vsemi stvarmi, ki so se nagrmadile, križale, leta in države in morja in ječe in obrazi in dogodki in misli in še zapori, razparani večerni oboki, iz katerih teče kri, in rane in pobegi in padci ... In enega življenja, več življenj, ni moč držati skupaj (9).

Protagonist se istoveti z ideologijo in se lahko počuti človeka le, če sledi svojim idealom. To je značilno predvsem za komunista in revolucionarja Cippica, ki takrat, ko izgubi vse, v kar je verjel, izgubi sebe samega (99). Padec komunističnih režimov in propad komunistične ideologije je zanj»[k]onec vsega, moj konec« (291), saj »[ž] elezna zavesa zgrmi kot giljotina in prereže srce, moje srce« (292) in tako prispeva k nadaljnjemu razkroju njegovega jaza.

V ospredju so predvsem določena zgodovinska obdobja, zlasti vojne (Napoleonove vojne, španska državljanska vojna, druga svetovna vojna), obdobja represije (ustanavljanje kazenskih kolonij na Tasmaniji, t. i. »črna vojna«, med katero evropski kolonizatorji iztrebijo tasmansko domorodsko populacijo, komunistična represija $\mathrm{v}$ povojni Jugoslaviji) in revolucije (Jorgensenova "miniaturna« revolucija na Islandiji, komunizem in geneza revolucionarnega gibanja). Tem pa je treba dodati tematiko, za katero se Magris še posebej zanima. To je povojna usoda komunistov iz italijanskega Tržiča, ki so se borili v španski državljanski vojni, bili zatirani pod fašizmom in deportirani v nacistična taborišča, se izselili v socialistično Jugoslavijo, naposled pa po razdoru med Titom in Stalinom pristali na Golem otoku.

Po protagonistovih idealističnih pričakovanjih naj bi revolucija prinesla konec zgodovine in popravila ponavljajoče se zgodovinske krivice, hkrati pa vendarle ohranila 
spomin na preteklost: »Revolucija [...] ne bo uničevala - sem mislil - potem ko bo zmagala in pri tem tudi razbila kakšno glavo; nasprotno, revolucija bo ohranjevala in negovala vse sledi človeške zgodovine, ki se bo naposled le končala, a se spominjala na svoje muke« (170).

Revolucija naj bi osmislila svet in zgodovino, protagonistu pa omogočila povratek domov. Toda zgodi se prav nasprotno, saj se prek revolucije, njenega propada in razblinjenja ideoloških sistemov, ki jih je zgradila, razkrije »nesmisel sveta« (59).

Zgodovina je v Magrisovem romanu slepa in nasilna, v svoji negativnosti pa se ponavlja, kajti, kot pove Magris v nekem intervjuju, »[d]omišljanje, da lahko enkrat za vselej rešimo svetovni problem in človeka spravimo z zgodovino, [...] ne vzdrži zgodovinske resničnosti« (Lunzer, 2010, 18-19). V romanu se vedno znova uresničuje možnost, da »zgodovina, ki ji ni a priori zajamčen nikakršen napredek, omahne nazaj do barbarstva, civilizacija do zverinstva, sožitje do sovraštva (Magris, 1996, 569-570).

Naslov romana je mogoče interpretirati z več zornih kotov, predvsem pa se navezuje na že omenjeno slepo nasilje zgodovine, ki je v besedilu ponazorjeno s pomorsko bitko za Kopenhagen. Nelson namreč noče ustaviti bombardiranja mesta, tudi ko se Danci že vdajo, temveč »približa daljnogled prevezanemu, pokritemu očesu, I'm damned if I see it, ne vidi nobene bele zastave« (77). Slepoto zgodovine ponazarja tudi mitološka pripoved o bitki Argonavtov z Dolioni (123-124, 265), ki se navezuje na Argonavte Apolonija Rodoškega (I, 1015-1028), natančneje, na italijanski prevod dela (Apollonio Rodio, 2010).

Zgodovina v vseh svojih obdobjih maliči in nepopravljivo odtujuje protagonistovo identiteto, »spremeni obraze« (36), uničuje. Jorgensen, denimo, sodeluje pri ustanovitvi kazenske kolonije: „odpravil sem se, da ustanovim mesto svoje pogube, kot sem pozneje zgradil svet, ki se je zrušil name« (79). Tako Jorgensen kot komunist Cippico sta povezana $\mathrm{z}$ mitološkim likom Jazona, ki »v kolhiško barbarstvo prinese luč civilizacije in hkrati novo barbarstvo« (59). Po eni strani torej uničenje, po drugi civilizacija - ustvarjati zgodovino namreč pomeni tudi pisati, urejati, poimenovati. Pred prihodom Evropejcev je tako Tasmanija brez zgodovine, "saj nima spomina. [...] Skoraj vsi kraji so še brez imena. Zgodovina je kamen, ki pljuskne v vodo in ne pusti sledi, sulica, ki švistne v gozdu« (83). Ko pa se Jorgensen vrne na Tasmanijo kot kaznjenec, se sčasoma začne udeleževati raziskovanja otoka in s tem ustvarja zgodovino, kajti »[d]elati Zgodovino - tudi revolucijo - pomeni predvsem ustvariti red v džungli, zarisati poti in ceste v brezobličnem močvirju« (245). Ko si kolonizatorji $\mathrm{z}$ mačetami utirajo pot skozi gozd, „temna zakotja $\mathrm{v}$ šumi, hudourniki, prostrane travnate ravnice stopajo iz pradavne teme in dobijo ime« (250), torej postanejo del zgodovine, vstopijo v čas. 


\section{Nedoločliive razsežnosti preteklosti}

Magris se pri razmišljanju o preteklosti naveže na znano Mannovo metaforo vodnjaka (Mann, 1985), katerega globin ni mogoče izmeriti (179). Toda v Magrisovem romanu vodnjak privzame izrazito negativne konotacije pozabe in propada (231). Medtem ko Mannova davna preteklost prehaja v vedno navzočo mitološko razsežnost, je Magrisov vodnjak zamašen (50), je »kloaka« (301): »Sonce prihodnosti je padlo $\mathrm{v}$ črn in globok vodnjak [...]. Pogledam v črni vodnjak: tisto blato je odsev mojega obraza. Tam spodaj sem, v tisti gnilobi rasem in uspevam: človek je govnač, ki uživa, da se žre» (301).

Ker razsežnosti preteklosti ni mogoče opredeliti, pripovedovalec ne zmore razločiti med njenimi ravnmi, ki se $\mathrm{v}$ romanu praviloma navezujejo tudi na različne geografske razsežnosti: »kaj imam jaz opraviti s tem zdaj, ne, prej, veliko let prej in zdaj, veliko let potem, pol stoletja, ki je več kot stoletje in pol, Van Diemenova zemlja, Katalonija, Barcelona ...« (263).

Protagonistovo zaznavanje časa je tako negotovo, da niti ni prepričan, v katero zgodovinsko obdobje sploh sodi: »še sam ne vem, ali sem star dvesto sedemnajst ali sedeminosemdeset let" (244); "sem dol, na ta konec sveta je prišel [neki izseljenec] leta 1952 z ladjo San Giorgio; eno leto za mano, ne, sto devetinštirideset let za mano« (56). N. Dupré v študiji, posvečeni konceptu meje v Donavi, opaža, da sta v romanu Na slepo "nedoločno in odsotnost meja stalna in neizogibna (Dupré, 2009, 194); njeno ugotovitev pa lahko prenesemo tako na geografske kot časovne razsežnosti.

\section{Časovna fragmentiranost kot pripovedna tehnika}

Na slepo ni le razmišljanje o zgodovini, marveč tudi o razdrobljenosti zgodovine, identitete in samega pripovednega glasu. Pripovedovalec že $\mathrm{v}$ prvih vrsticah romana problematizira avtodiegetično pripoved in se sprašuje, ali je sploh mogoče pripovedovati o zgodovini v prvi osebi, torej pripovedovati o zatiranju, trpljenju in maličenju lastne identitete.

Izkaže se, da je časovna fragmentacija ena temeljnih pripovednih tehnik v romanu, na kar nakazuje že Magrisova načelna pripomba, da "pisati pomeni tudi razgraditi zgodovinski čas [...], razparati Penelopin prt in ga ponovno stkati« (Magris, 2008, 5). Bolj specifično pa avtor glede pripovedne tehnike v romanu Na slepo poudari svoje dolgoletno zanimanje za usodo tržiških komunistov in nasploh zapornikov na Golem otoku, za katero se mu oblika linearne zgodbe ne zdi primerna: 
dolga leta sem bil obseden z zgodbo deportirancev na Golem otoku komunistov, ki so bili najprej zaprti v nacističnem taborišču, nato pa še $\mathrm{v}$ komunističnih gulagih. Pred mnogimi leti sem začel pisati tudi linearen roman, vendar se to ni izšlo. [...] Tako sem napisal roman Na slepo [...], ki je zasnovan kot labirintska pripovedna struktura, kot na glavo obrnjena Jakobova lestev, ki vodi v podzemlje zgodovine, še zlasti zgodovine dvajsetega stoletja (Magris, 2008, 27).

L. Governatori v Magrisovih besedilih prepoznava »dvojno logiko«, v kateri se kombinirata "neskončno veliko in neskončno majhno (Governatori, 1999, 53), torej celota - zgodovina $\mathrm{v}$ velikih potezah - in drobec - življenje posameznika, kar lahko prepoznamo tudi v romanu $\mathrm{Na}$ slepo. Razdrobljenost omenja tudi E. Scalfari, ki v romanu prepoznava »inovativno formo«: "pripovedovanje z glasom lucidnega norca, ki zdrobi enotnost časa in kraja« (Scalfari, 2005, 49).

$\mathrm{Na}$ to, da čas $\mathrm{v}$ romanu še zdaleč ni premočrten, opozarjajo številni kritiki. F. Airoldi Namer govori o "mnogoterosti časov« (Airoldi Namer, 2006, 273), po mnenju F. Marenca je v romanu »linearno pojmovanje časa odpravljeno« (Marenco, 2008, 15), E. Pellegrini poudarja »kompleksno, labirintsko časovno razplastenost« in »heterogeno rabo časovnih kategorij« (Pellegrini, 2006, 37), medtem ko U. MusarraSchröder meni, da pripovedni glas "popolno beleži mnogotero, protislovno, zmedeno realnost sodobne zgodovine« (Musarra-Schröder, 2007, 134). S. Parmegiani poseže po posrečeni Shakespearovi metafori in ugotavlja, da je v Magrisovem romanu »[č]as večno iz sklepa spahnjen« (Parmegiani, 2011, 118).

Fragmentacija časa je povezana $\mathrm{z}$ drobljenjem identitete, ki je posledica splošne "krhkosti jaza«, o kateri avtor razmišlja tudi v članku »Identiteta ali negotovost" (Magris, 2003, 521). Glede romana $\mathrm{Na}$ slepo pa Magris poudarja »neprestano drobljenje in rekonstruiranje identitete, eksistencialno stanje, $\mathrm{v}$ katerem junak slepo živi, ljubi, deluje in slepo utrpi nasilje« (Magris, 2008, 28). Gre za pripoved o "fascinantno ponorelih drobcih življenja» (Paccagnini, 2012, 57), katerih časovna sosledica je nujno fragmentirana, saj po Magrisovem mnenju »koncept urejenega in zaključeno sestavljenega življenjepisa ni več mogoč« (Magris, 1998, 86). Primer za to je protagonist romana Drugo morje (Un altro mare, 1991) Enrico Mreule, o katerem Magris pove, da mu je uspelo odkriti le nekatere podrobnosti iz njegovega življenja, vendar je ob njih lahko doumel slog njegovega življenja (Magris, 1998, 86).

Bralčeva naloga je, kot ugotavlja tudi S. Parmegiani, da "prek raztresenih drobcev zlepi skupaj koščke življenj« (Parmegiani, 2011, 118). Fragmentacija identitete pa je posledica mučenja in trpljenja, ki ga je protagonist prek svojih različnih identitet utrpel zaradi zgodovinske represije: 
čas se zgosti, raztegne se, velik kuščar, ki stalno izgublja svoj rep; déli mene se pogrezajo v temne vode. Otipavam si roke, obraz, prsi, da bi razumel, ali sem še cel [...]. Deli mene plavajo razmetani po razsrjenem morju, [...] izginem, ne, tisti odpadki so moji, jaz sem, nimate pravice, vržem se v vodo, da bi jih rešil, zlepil jih bom in bom spet jaz (290).

Za pripovedno tehniko $\mathrm{v}$ romanu so značilni pogosti preskoki med različnimi časovnimi obdobji, "nenehna križanja časovnih ravni (ki malodane privedejo do ukinitve same časovnosti) «(Paccagnini, 2005, 35) in med katerimi meje še dodatno zabrisuje prvoosebni pripovedni glas. Tako se, denimo, triinšestdeseto poglavje začne s pripovedjo o Cippicovi povojni emigraciji v Avstralijo, vendar prvoosebna pripoved kmalu preskoči v leto 1825, torej v čas Jorgensenove deportacije na Tasmanijo (212). Nato se - prek veznega člena mitološke pripovedi o zlatem runu - spet vrne v povojni čas. Cippico se zdaj spominja, kako je prvič prispel iz Avstralije na Reko, to pa se je pripetilo »prej, veliko prej, morda še preden sem vrgel sidro v izliv Derwenta, v nekem bolj davnem času« (216), s čimer je kajpak mišljeno leto 1803, ko je Jorgensen prvič priplul na Tasmanijo. Do preskoka med različnima časovnima obdobjema tako pride nenadno, med enim in drugim stavkom iste povedi, ne da bi ga spremljala kakšna posebna opozorilna znamenja. Podoba Möbiusovega traku, s katero E. Saccone mojstrsko ponazori prehajanje med locus amœnus in locus terribilis $\mathrm{v}$ Ariostovem Besnečem Orlandu, se zato zdi primerna tudi za opis prehajanja med časovnimi ravnmi v romanu $\mathrm{Na}$ slepo: „do prehoda pride [...] kot po Möbiusovem traku, brez skokov ali očitnih težav. Ena in dve; dve površini in ena sama; ena znotraj in druga zunaj; prva je nasproti druge, vendar jo hkrati nadaljuje, razširja in presenetljivo podaljšuje « (Saccone, 1974, 247).

$\mathrm{V}$ šestem poglavju Jorgensen kot otrok na Danskem pod povečevalnim steklom gleda safirje, ki jih obdeluje njegov brat Urban, in se ob tem paradoksalno spominja morja na Tahitiju, kjer pa bo seveda pristal šele veliko pozneje, kot odrasel mož, ko se bo vračal s svojega prvega potovanja v Avstralijo (1805-1806). Takoj zatem pripoved preide na Miholašćico na Cresu, kamor rad zahaja Cippico, pa spet nazaj v otroštvo Jorgensena, ki naj bi ga mati ne ljubila (48-51). Z Jorgensenove matere pripoved neposredno preide na Cippicovo mater na Tasmaniji pa spet nazaj v Jorgensenovo otroštvo:

Kaj pa je ta zgodba o moji materi, češ da me ni ljubila? [...] Tisti jasni nasmeh na toplem in rjavem obrazu, njena usta tik ob mojem licu na bregu Derwenta, razprtem proti morju, njena nenavadna, neverjetno mehka, nekoliko grlna italijanščina [...]. Če sem le kaj imel, je bil to njen nasmeh. No, res, v Christiansborgu je bila $\mathrm{z}$ mano stroga; redko me je vzela v naročje, kot je običajno počela z Urbanom (49-50). 
Še enemu številnih primerov prehajanja med časovnimi ravnmi smo priča v sedmem poglavju (56-64), kjer se pripoved začne v sedanjosti (v času Cippicove terapije $\mathrm{v}$ psihiatrični bolnišnici, ki je hkrati pripovedni čas), preskoči v obdobje Jorgensenovega življenja, nato na Cippicovo bivanje v Avstraliji po drugi svetovni vojni pa spet v tasmansko kaznilnico Port Arthur in nazaj v psihiatrično bolnišnico. Zatem preide na Jorgensenovo bivanje na Tasmaniji, na Cippicov povojni odhod v Jugoslavijo, njegovo deportacijo na Goli otok, na Jorgensenovo mladost v Angliji in na Danskem, pa spet na Goli otok in Port Arthur. Na koncu poglavja se pripovedovalec vpraša, ali se je po Golem otoku sploh mogoče vrniti domov in znova zaživeti, pri tem pa pripoved preide $\mathrm{v}$ zunajčasovno mitološko razsežnost:

Kam, kako naj se vrnemo domov? Argo na begu iz Kolhide z ukradenim runom zablodi v Sirto, od koder ni poti nazaj. Kajti povsod so močvara, blato in alge, ki jih preplavlja morska pena. Argo nasede, zmečkano runo obvisi; na krovu junaki propadajo, kot propada stara ladja. [...] Kako, kam se vračati z Golega otoka? [...] Argo, ki jo junaki po puščavi nosijo na ramenih, naposled dospe do morja ter najde pot domov. Naša ladja pa nas je zasula in njen trup nas je zmečkal (63-64).

Časovni preskoki se pogosto izražajo tudi prek protagonistovih problematičnih odnosov z ženskimi liki. Pri tem prehode s Cippica na Jorgensena povezuje mitološki Jazonov lik, medtem ko se ženski liki (Marija, Marie, Marica, Marja) vsi po vrsti prepoznavajo v Medeji. Kot zadnji primer ponujamo kratek, a dokaj kompleksen odlomek, v katerem se v prvi povedi Cippico obrača na Marijo. Ta mu je pomagala pobegniti z Golega otoka, zaradi tega prebila tri leta v jugoslovanskih zaporih, zatem pa prek Italije emigrirala v Avstralijo. V drugi povedi pripovedni glas govori o Jazonu (v tretji osebi, toda $\mathrm{v}$ sedanjiku, ki označuje zunajčasovnost mitološke pripovedi). V tretji povedi v pripovedovalcu prepoznamo Jorgensena, ki govori o ustanovitvi Hobarta, torej o začetku 19. stoletja. V četrti besedo znova prevzame Cippico in nadaljuje s pripovedovanjem o Jazonu $\mathrm{v}$ tretji osebi, vendar pa tokrat Marijo popolnoma poistoveti z Medejo, saj se na mitološki ženski lik obrača neposredno v drugi osebi:

Prišla si sem dol, da bi mi zvesto sledila v nesrečni usodi. Medeja sledi Jazonu, ki se vrne v svoje knežje mesto. Jaz sem večji knez od njega, saj sem svoje mesto ustanovil. Povlekel sem te sem dol - nisem sam kriv, tudi Jazona so obrekovali, ker je s tabo v Korintu slabo ravnal, a treba je razumeti (253).

\section{Zunajčasovnost}

Nepremočrtni, razdrobljeni čas spričo nedojemljivosti preteklosti prehaja $\mathrm{v}$ zunajčasovnost, $\mathrm{v}$ kateri pripovedovalec išče mitološke interpretacije zgodovinskega 
nasilja. V romanu ima zunajčasovna razsežnost dve popolnoma nasprotujoči si vrednosti. Po eni strani gre namreč za izrazito pozitivno ovrednoteni koncept "prepričanja«, ki ga je obravnaval goriški filozof Carlo Michelstaedter v razpravi Prepričanje in retorika (La persuasione e la rettorica, 1910, prva izdaja Genova 1913). Magris se "prepričanja« dotakne v številnih delih, še posebej v Drugem morju (Magris, 2011), in ga v predgovoru k Neskončnemu popotovanju (L'infinito viaggiare, 2005) opredeli takole:

Prepričanje pomeni, [...] da smo sposobni živeti vsak trenutek, ne le posebnih in izjemnih trenutkov, in to tako, da ga ne žrtvujemo prihodnosti, izničimo $\mathrm{v}$ načrtih in programih in ne gledamo nanj kot na nekaj, kar mora zgolj hitro miniti, da lahko nato dosežemo kaj drugega. V življenju imamo skoraj vedno preveč razlogov, da upamo, da bo čim hitreje minilo, da bo sedanjost čim prej postala prihodnost; [...] torej ne živimo zato, da bi živeli, temveč da bi že doživeli, da bi bili bližje smrti, da bi umrli (Magris, L'infinito, 2005, VIII).

Medtem ko protagonistu Drugega morja ne uspe resnično udejanjiti "prepričanja«, je v romanu Na slepo to pogojno mogoče, a le v otroštvu (48-49). V otroštvu čas ne mineva, temveč stoji, je nepremičen; po tem srečnem življenjskem obdobju se »začenja smrt «(54). Podobe nepremičnosti so povezane z Jorgensenovim otroštvom, med katerim v delavnici njegovega očeta v palači Christiansborg vlada "podmorska negibnost « (48). Medtem ko Jorgensen tu opazuje safirje, je čas »raztegnjen« (49) in »[s]reča miruje, negibna je« (49). Za Cippica se zunajčasovnost kot sreča uresniči v Maričinem poljubu: Srećan Božić, mi je rekla Marica in mi ponudila svoje ustnice. Nedolžen božični poljub, kot je v navadi, ki postane drug poljub - čas se raztegne, ustavi, zdrsne v usta. Tam [...] je bilo moje življenje dolg rečni tok z vsemi vijugami, slapovi, razširninami. Ta delček mojega življenja je večji od mojega življenja, minuta lahko vsebuje ure, ura leta, čeprav tako naglo utrne (170-171).

Toda v romanu prevladuje izrazito negativen koncept zunajčasovnosti. Večnost pomeni predvsem trajajoče, ponavljajoče se trpljenje. Protagonist pravzaprav niti ne ve, ali je živ ali mrtev $(127,277-279)$, v vsakem primeru pa večno življenje dojema kot obsodbo (42); tudi kaznjenci so »obsojeni do konca svojih dni, za vse svoje življenje. Ali morda obsojeni na življenje?« (279). Ko je Jorgensenova smrtna kazen omiljena in je namesto tega obsojen na prisilno delo, se počuti kot »mrtvec, ki mora ostati na kopnem, ker ga je Haronov brod zavrnil« (86). Podoba večnosti kot brezkončnega lagerja se ne navezuje le na individualno identiteto, temveč na identiteto mnogih, ujetih v kolesje zgodovine: „Čemu prebujati tistega, ki spi? Kako bi bil srečen, če bi me pustili počivati v miru; strašna je misel, da se bomo poslednjega dne vsi zbudili; srečni poslednji dan, ki pa postane nesrečni prvi dan, začetek večnosti, začetek lagerja, ki se ne bo nikoli končal ...« (47). 
Pripovedovalec se celo sprašuje, ali sta čas in zgodovina po Golem otoku sploh še možna ali pa je po srečni mladosti možno le še uničenje - tudi uničenje časa in spominov: "Moje otroštvo, moja mladost, sta kmalu, hitro minili. Ponza, Guarrama [sic], Velebit, Dachau, Goli otok in ... in kaj, po Golem otoku? Ne spominjam se, toliko let, potisnjenih v vrečo, težkih kakor svinec« (163-164).

Ker je trpljenje skozi zgodovinska obdobja vselej navzoče, »[s]težka določimo, kaj je prej in kaj pozneje: Goli otok, Dachau ali Port Arthur; bolečina je vedno tu in zdaj« (18). Spričo ponavljajočega se zgodovinskega nasilja se različne ravni preteklosti pomešajo: »Port Arthur pred poldrugim stoletjem, Dachau in Goli otok včeraj, zdaj« (23). Politični režimi se menjajo, a v svojem temelju ostajajo represivni, zato je protagonist $\mathrm{v}$ različnih zgodovinskih obdobjih vsakič znova obtožen, da jim nasprotuje: «Zakaj sem se moral vselej braniti pred obtožbo, da sem izdajalec? Zakaj se me večno drži ta sloves, da sem sovražnik ljudstva, danski, angleški, kominformovski, zahodnjaški vohun ...«(120).

Koncept ponavljajoče se zgodovine, v kateri sta vedno navzoči nasilje in zatiranje, lahko opišemo tudi z izrazom, ki ga L. Governatori sicer uporabi za Magrisov kratki roman Sklepanje o sablji (Illazioni su una sciabola, 1984), kot »krožno časovno vizijo«; v tej se "preteklost steka v prihodnost, ta pa v preteklost, prek večne sedanjosti« (Governatori, 1999, 47). Tudi pripovedovalec v romanu Na slepo namreč ugotavlja, da je »vse [...] prisotno, vse se dogaja danes« (179). S tem se lahko navežemo na sicer pozitivni koncept »ne-časa«, ki ga Magris opisuje v sestavku, posvečenem Trstu, v delu Itaka in onkraj (Itaca e oltre, 1982). Avtor tu izpostavlja "privlačnost tržaškega nečasa» (Magris, 1990, 15), ki ni premočrten, temveč "pretrgan in protisloven čas, ki gre naprej in nazaj in se vsakokrat vrne k samemu sebi, zadržuje tek stvari, jih dela vse istočasne, jih razvršča drugo ob drugi« (Magris, 1990, 13).

Ko se v romanu $\mathrm{Na}$ slepo protagonistova identiteta do skrajnosti razdrobi, se ta znajde $\mathrm{v}$ zunajčasovni razsežnosti, kjer negativna plat zunajčasovnosti doseže svoj višek: »znajdem se sredi vrtinčenja, v črni luknji, ki me negibna v hipu pogoltne. [...] [V] črni luknji čas stoji [...]. V lagerju kri utripa s stoletno počasnostjo [...] in tu se vse bolj pogrezam čisto počasi, skoraj nepremičen, potem negiben« (108).

Zgodovinski dogodki, ki so $\mathrm{v}$ romanu osrednjega pomena, so interpretirani prek epizod argonavtskega mita, denimo prek že omenjene bitke Argonavtov z Dolioni, ki ponazarja interne boje med tistimi, ki so - ali naj bi bili - na isti strani. Ob tem lahko vsekakor pritrdimo definiciji S. Parmegiani, da so miti »bistveni za strukturno povezanost Magrisovega besedila« (Parmegiani, 2011, 123). Mitološka metafora za ponavljajočo se zgodovino je zlato runo, ki ponazarja oblast; tako Cippico kot Jorgensen imata svojo vzporednico v Argonavtih, vendar predvsem z negativnimi konotacijami uničenja in nasilja: 
Runo duši; smrt prinaša, vsem tistim, ki se ga dotaknejo. Argo prepluje morje, da bi ukradla runo, to pomeni, da bi ubijala in umrla. Brž ga moramo vrniti, da ne bo prepozno in bo spet tekla krvi [sic]. A komu naj ga vrnemo? Vsak prejšnji lastnik, ki ga naslednji izropa, je uzurpator, ki si ga je zločinsko prilastil. Vrniti ga je treba živali, ki so jo zaklali in odrli, da bi jo žrtvovali bogovom, vedno hlepečim po krvi (267).

$\mathrm{V}$ sklepnem delu romana se prvoosebni pripovedni glas poistoveti z Jazonom in pripoveduje o lastni smrti, ki je podobna Jazonovi. Protagonist se primerja z ladjo Argo in z njeno zunajčasovno razsežnostjo:

Argo, potem ko sem jo posvetil Pozejdonu in jo pustil na bregu morja, [je] sicer trohnela in razpadala na kose, a verniki, ki so jo prihajali častit, so stalno menjavali tiste kose, zdaj enega, zdaj drugega. Tako je bila ladja zmerom tam, antična in nova, cela in nesmrtna, druga pa spet ista, kot jaz, kot bogovi (305).

Po desetletjih in stoletjih ponavljajočega se nasilja protagonist tako začasno izstopi iz zgodovinske razsežnosti in vstopi v mit. Toda v nasprotju z Argo, ki jo bogovi dvignejo na nebo, »med večna ozvezdja« (305), se udeležencu zgodovinskih dogodkov ni dovoljeno dvigniti, marveč le »spustiti k bogovom « (Magris, 2005, 335). ${ }^{3}$

\section{Sklep}

Koncept časa v Magrisovem romanu Na slepo je izjemno kompleksen. Prepletanje, prekrivanje in razdrobljenost identitet hodijo $\mathrm{z}$ roko $\mathrm{v}$ roki s fragmentirano percepcijo časa in nezmožnostjo ločevanja med različnimi ravnmi preteklosti. Identitete protagonistov so tesno povezane z zgodovino, predstavljeno kot slepo in nasilno silo, ki prek ponavljajočih se represivnih vzorcev uničuje posameznika. Avtor kot možno interpretacijo zgodovinskih dogodkov ponuja zunajčasovno mitološko pripoved, predvsem mit o Argonavtih in zlatem runu. Pripovedni glas se naposled poistoveti z Jazonovim, medtem ko se neopredeljivi čas razkroji v zunajčasovnosti.

\section{Viri}

Apollonio Rodio, Le argonautiche, prev. Paduano, G., Milano 2010.

Magris, C., I luoghi della scrittura: Trieste, v: Itaca e oltre: i luoghi del ritorno e della fuga in un viaggio attraverso alcuni grandi temi della nostra cultura, Milano 1982, str. 278-284, prev., Kraji pisave: Trst, Ars vivendi 9, 1990, str. 10-15.

Magris, C., Un altro mare, Milano 1991, prev. Simoniti, V., Drugo morje, Ljubljana 2011.

3 Prev. Irena Prosenc Šegula. 
Magris, C., Illazioni su una sciabola, Milano 1992.

Magris, C., Kdo piše nepisane zakone bogov?, prev. Vatovec, B., in drugi, Sodobnost 44/6-7, 1996, str. 565-570.

Magris, C., Claudio Magris: la scrittura e le frontiere, v: Scrittori a confronto. Incontri con Aldo Busi, Maria Corti, Claudio Magris, Giuliana Morandini, Roberto Pazzi, Edoardo Sanguineti, Francesca Sanvitale, Antonio Tabucchi (ur. Dolfi, A., in drugi), Rim 1998, str. 57-92.

Magris, C., Identità ovvero incertezza, Lettere italiane 4, 2003, str. 519-527.

Magris, C., Prefazione, v: L'infinito viaggiare, Milano 2005, str. VII-XXVIII.

Magris, C., Alla cieca, Milano 2005.

Magris, C., Alla cieca, Milano 2005, prev. Brecelj, V., Na slepo, Ljubljana 2009.

Magris, C., The Self That Writes, v: Almost Island Dialogues: Two, New Delhi 2008, str. 1-29, http://almostisland.com/monsoon_2008/essay/pdfs/the_self_that_writes.pdf [24. 6. 2012].

\section{Literatura}

Airoldi Namer, F., Straniero da dove? Claudio Magris e il romanzo »Alla cieca«, Narrativa 28, 2006, str. 267-280.

Ciccarelli, A., Sette domande a Claudio Magris, Italica 3, 2004, str. 402-423.

Dupré, N., Per un'epica del quotidiano. La frontiera in Danubio di Claudio Magris, Firence 2009.

Governatori, L., Claudio Magris, l'opera saggistica e narrativa, Trst 1999.

Jančar, D., Zgodovina, njen slepi nemir, v: Magris, C., Na slepo, Ljubljana 2009, str. 309-311.

Lunzer, R., »La nostra verità è il cammino «. A colloquio con Claudio Magris, Italienisch 1, 2010, str. 2-25.

Mann, Th., Predigra. Pot v pekel, v: Jožef in njegovi bratje, prev. Moder, J., Ljubljana 1985, str. 13-60.

Marenco, F., Che ne ha fatto della storia il romanzo moderno?, La modernità letteraria 1, 2008, str. 15-21.

Michelstaedter, C., La persuasione e la rettorica, 1910, prev. Bednarich, J., Prepričanje in retorika, Ljubljana 2011.

Musarra-Schröder, U., La geografia della Storia: »Alla cieca« di Claudio Magris, Otto / Novecento 1, 2007, str. 123-135. 
Paccagnini, E., Sull'arca di Magris, nel mare delle verità, Corriere della Sera, 27. april 2005, str. 35.

Parmegiani, S., The Presence of Myth in Claudio Magris's Postmillennial Narrative, Quaderni d'italianistica 32, 1, 2011, str. 111-134.

Paccagnini, E., Magris, le molte frontiere dell'anima, Corriere della Sera, 21. april 2012, str. 56-57.

Pellegrini, E., La biografia sdoppiata di Magris: »Alla cieca« di Claudio Magris, La rivista dei libri 4, 2006, str. 35-38.

Saccone, E., Il »soggetto« del Furioso, v: Il »soggetto « del furioso e altri saggi tra quattro e cinquecento, Napoli 1974, str. 201-247.

Scalfari, E., Se il mondo è un delirio, Repubblica, 19. maj 2005, str. 49. 
Irena Prosenc Šegula

\section{"History is not linear ... it zigzags": The Perception of Time in Magris' novel Blindly}

Keywords: contemporary Italian literature, Claudio Magris, time, history, identity, myth, Argonauts

In his novel Blindly Claudio Magris develops a complex perception of time. This perception is intertwined with reflections on history, identity and the status of the narrative voice. History, which "is not linear" but "zigzags" is presented as a continuously repetitive phenomenon, while temporal time is impossible to measure. The status of the autodiegetic narrator becomes highly problematic as the narrative voice assumes identities belonging to various historical periods ranging from the late $18^{\text {th }}$ to the $20^{\text {th }}$ centuries.

The novel focuses on repressive historical periods which deform the protagonists' identities, thereby conveying an image of history as a blind and violent force. Fragmentation, one of the basic narrative techniques in the novel, concerns time sequences as well as the protagonists' identities and the narrative voice itself. As the protagonists' lives can only be narrated as fragments, there are frequent passages between different time periods. These merge into extratemporality, which is associated with eternal suffering stemming from the repetitive, oppressive nature of history. The historical events depicted in the novel are interpreted through the extratemporal dimension of the Argonaut myth. 